\title{
Anatomical Variations of Thyroid Glands in Northeastern-Thai Embalmed Cadavers
}

\author{
Variaciones Anatómicas de la Glándula Tiroides en \\ Cadáveres Embalsamados del Noreste de Tailandia
}

Chanwit Maneenin ${ }^{1}$; Naowarat Maneenin ${ }^{2} \&$ Sitthichai Iamsaard $^{3,4}$

MANEENIN, C.; MANEENIN, N. \& IAMSAARD, S. Anatomical variations of thyroid glands in Northeastern-Thai embalmed cadavers. Int. J. Morphol., 37(1):136-140, 2019.

SUMMARY: This study aimed to investigate the variation patterns of thyroid glands in embalmed cadavers donated for anatomical studying and research in the northeastern part of Thailand. The crossed-sectional descriptive study was applied to systemically observe the thyroid gland in abnormality of 45 embalmed cadavers. The study was conducted in the Anatomy Laboratory of College of Medicine and Public Health, Ubon Ratchathani University. The indications of thyroid gland abnormalities were recorded by photographs before classification of data used further in a descriptive analysis using SPSS. The results showed that 8 of the 45 cadavers (17.8 \%) were observed with thyroid gland abnormality (4 males; $8.9 \%$ and 4 females; $8.9 \%$ ). Such variations could be classified into 3 types; pyramidal lobe $(8.8 \%)$, levator glandulae thyroideae $(2.2 \%)$ and the co-existing of levator glandulae thyroideae $(8.8 \%)$, respectively. The thyroid gland abnormality observed in this study was mainly related to many previous reports. Besides the number of thyroid variations are a crucial indication of thyroid gland abnormality recurring, these gland abnormalities are susceptible to the operation of radiology physicians in thyroidectomy and tracheostomy.

KEY WORDS: Anatomical variations; Thyroid gland; Pyramidal lobe; Levator glandulae thyroideae.

\section{INTRODUCTION}

Thyroid is the first gland of human body that develops in the embryos after the $24^{\text {th }}$ day of fertilization. Due to the surface tension of FGE signaling pathway, the endoderm located around the surface of primordial pharynx becomes thicker anddevelops into thyroid primodium. This process takes place at the same time with the development of a tongue. The development of both organs descends downward into the pharynx cavity, passing through the ventral of hyoid bone and larynx bones. At its early stage of development, thyroid gland is linked with the tongue via a very small tube called, thyroglossal duct. Thyroid primodium is originally formed as an empty tube however tissue and flesh gradually develop in it and when fully grown the organ takes a bisectional structure that is joined together by a tissue called isthmus. In week 7 , the thyroglossal duct is dissolved while thyroid gland is affixed to its position and looks exactly like an adult's regular thyroid gland (Moore \& Persuad, 2003; Saddler, 2010; Moore et al., 2013). Adult's thyroid gland is supported by a lot of arteries, which makes it look reddish. A fully-grown thyroid gland is located at the front of the throat around the area of the second to third tracheal ring which is aligned to the area of the fifth cervical to first thoracic vertebrae (C5-T1) (Hollinshead, 1961; Marshall, 1985; Kaplan, 1994; Skandalakis, 2004). Thyroid gland is divided into left and right lobes that are joined together by isthmus (Ranade et al., 2008; Standring, 2008; Phukon et al., 2012). The anatomy alteration of thyroid gland involves distortion of the glands' sizes and shapes (Joshi et al., 2010; Prakash et al., 2012). Specifically in recent research, the pyramidal lobe was found separating from the left lobe. The tip of the pyramidal lobe was converted into a fibro-muscular band that insertion to the edge of hyoid bone called levator glandulae thyroideae (Moore \& Persuad; Standring; Chaudhary et al., 2013; Rajkonwar \& Kusre, 2016). Due to the fact that there has been no investigation of the thyroid gland abnormality in embalmed cadavers in Thailand, the researchers found it fascinating to conduct a research into this area in order to identify the thyroidal abnormality types among the embalmed bodies in northeastern Thailand.

\footnotetext{
${ }^{1}$ Department of Anatomy, College of Medicine and Public Health, Ubon Ratchathani University, Ubon Ratchathani, 34190, Thailand.

${ }^{2}$ Department of Epidemiology and Biostatistics, Faculty of Public Health, Khon Kaen University, Khon Kaen, 40002, Thailand.

${ }^{3}$ Department of Anatomy, Faculty of Medicine, Khon Kaen University, Khon Kaen, 40002, Thailand.

${ }^{4}$ Center for Research and Development of Herbal Health Products, Faculty of Pharmaceutical Sciences, Khon Kaen University, Khon Kaen, 40002, Thailand.
} 


\section{MATERIAL AND METHOD}

The sample size was calculated from the formula for estimating population proportion (Wayne, 1995) which was estimated using a confidence interval of $95 \%$, and acceptance error of $15 \%$ and a prevalence of pyramidal lobe of $46 \%$ (Veerahanumaiah et al., 2015). Thus, the required sample size was at least 43 embalmed cadavers. The investigation of the abnormality of thyroid gland was conducted via a crossed-sectional descriptive study, which was done in the Anatomy Laboratory of College of Medicine and Public Health, Ubon Ratchathani University from 2014 to 2017. The specimens were 45 of embalmed bodies who were residents of the Northeastern region when they were alive. The embalmed cadavers were given by Department of Anatomy of Khon Kaen University. The crossed-sectional investigations of the embalmed cadavers were conducted during a gross anatomy study of thyroid glands, which was a class for medical students. The skin on the front side ofthe neck was carefully dissected. The data relating to the characteristics of thyroid glands and its supporting arteries and nerve was recorded. When spotting the abnormalities such as the development of pyramidal lobe and levator glandulae thyroideae (LGT), the researchers was observed the origin and insertion, taking photos and recorded the data on the form. The data was analyzed by using SPSS program. The study protocol was approved by the Ehical Review Board of Ubon Ratchathani University (Certificate of approval number: UBU - REC-32/2561)

\section{RESULTS}

The samples were 45 of embalmed cadavers, 25 males

Table I. Characteristics of embalmed cadavers.

\begin{tabular}{lcc}
\hline Characteristics & Number & Percentage \\
\hline Sex & & \\
$\quad$ Male & 25 & 55.6 \\
Female & 20 & 44.4 \\
Thyroid gland & & \\
$\quad$ Normal & 37 & 82.2 \\
Abnormal & 8 & 17.8 \\
\hline
\end{tabular}

$(55.6 \%)$ and 20 females $(44.4 \%)$. Thyroid gland abnormality was observed in 8 of the samples $(17.8 \%$, as in Table I). Four of the cases with thyroid abnormality were males and four others were females, which is about 8.9 percent of a total number of the sample (Table II).

The thyroid gland abnormality observed in this research were classified into three categories, type I) thyroid gland with right lobe, left lobe, isthmus and pyramidal lobe, type II) thyroid gland with right lobe, left lobe, isthmus and Levator glandulae muscle, and type III) thyroid gland with right lobe, left lobe, isthmus and the co-existing of pyramidal lobe and levator glandulae thyroideae (Table II). Among the male cadavers, type I thyroid gland abnormality was observed. As shown in Figure 1A, the beginning of pyramidal lobe was attached to the right lobe of thyroid gland and isthmus while its ending was found at the same plane of thyroid prominence. In addition, type III was observed in three of the male cadavers as shown in Figure 1B, 1C, and 1D. In 1B and 1C, pyramidal lobes were found separate from the right lobe of thyroid gland. In 1D, however, the separation was on the left lobe of thyroid gland. At the end of three cases pyramidal lobes were development to fibrous band of levator glandulae thyroideae. These fibrous bands were found insertion to the edge of hyoid cartilage, the gland was supplies by superior thyroid artery which is a branch of the common carotid artery. The venous was drained from thyroid gland via inferior thyroid vein to left brachiocephalic vein. The type II of thyroid gland abnormality was not observed in the male cadavers (Table II).

In the investigation of female cadavers, type I were observed in two cadavers (Figure 1E and 1F). In Figure 1E, pyramidal lobe was found detaching from the right lobe of thyroid gland and isthmus while the separation was observed on the left side of thyroid gland and isthmus in Figure 1F. The edges of pyramidal lobes observed in Figure $1 \mathrm{E}$ and $1 \mathrm{~F}$ were found horizontally parallel to inferior-lateral border of thyroid cartilage and inferior thyroid notch, respectively. The gland was supplied by superior thyroid artery and venous drained away via left brachiocephalic vein. Type II of thyroid gland abnormality was founded one case, characterized by thyroid gland with right lobe, left lobe, isthmus and levator glandulae thyroideae was also observed in a female body as shown in

Table II. Classifications of thyroid gland abnormalities.

\begin{tabular}{lcccc}
\hline & & & Classific ations of Thyroid Gland Abnormalities (N=8) \\
\cline { 3 - 5 } & Characteristics & Type I : & Type II : & Type III : \\
& & $\begin{array}{c}\text { Pyramidal lobe (PL) } \\
\text { Number }\end{array}$ & $\begin{array}{c}\text { Levator glandulae thyroideae (LGT) } \\
\text { combined LGT } \\
\text { Number }\end{array}$ & Number \\
\hline Sex & & & 3 \\
Male $\quad(n=4)$ & 1 & 0 & 1 \\
Female $(n=4)$ & 2 & 1 & 3 \\
\hline
\end{tabular}



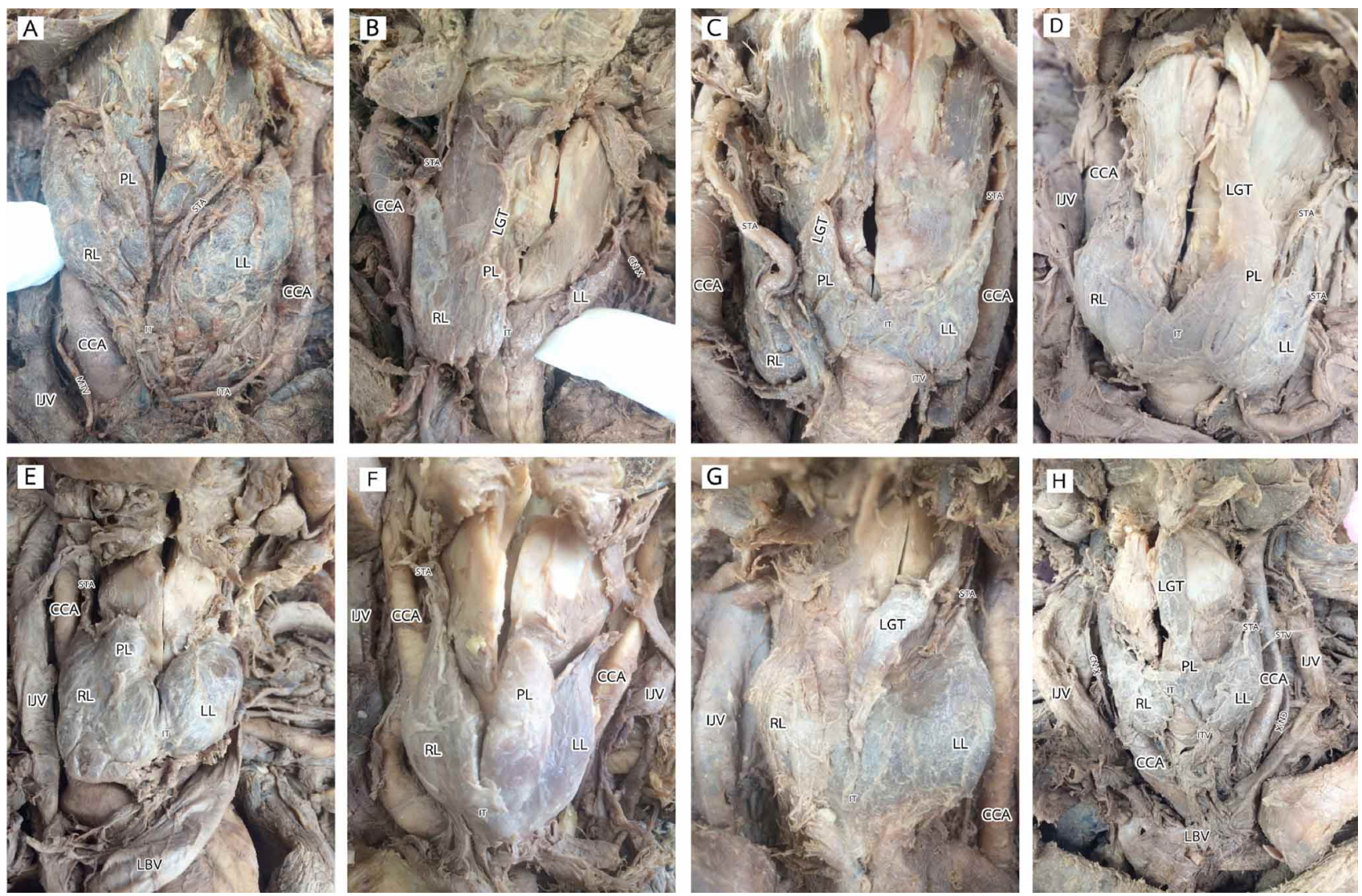

Fig. 1. Showing 8 cases (A to $\mathrm{H}$ ) of the thyroid gland variations observed in Northeastern-Thai Embalmed Cadavers. IJV=Internal jugular vein, $\mathrm{CN} \mathrm{X}=$ Vagus nerve, $\mathrm{CCA}=$ Common carotid artery, $\mathrm{RL}=\mathrm{Right}$ lobe, $\mathrm{IT}=\mathrm{Isthmus,} \mathrm{LL}=\mathrm{Left}$ lobe, $\mathrm{PL}=\mathrm{Pyramidal}$ lobe, LGT= Levator glandulae thyroideae, ITV=Inferior thyroid vein, LBV= Left brachiocephalic vein, STA= Superior thyroid artery, STV= Superior thyroid vein.

Figure 1G. The levator glandulae thyroideae looked like a muscle with the fibrous band at its end. This band insertion to hyoid which is a cartilage supported by superior thyroid artery. Type III of thyroid gland abnormality, characterized by the presence of Thyroid gland with right lobe, left lobe, isthmus and the co-existing of pyramidal lobe and levator glandulae thyroideae, was observed in a female cadaver as shown in Figure $1 \mathrm{H}$. This thyroid gland distortion was remarked by the development of pyramidal lobe at the center of isthmus. Pyramidal lobe developed in this position turned into a form of levator glandulae thyroideae and stretched along the center of thyroid cartilage. The end of the fibrous muscle insertioned to hyoid cartilage. The gland is supplied by superior thyroid artery. The venous was drained from superior thyroid vein to internal jugular vein. The inferior thyroid vein was drained to left brachiocephalic vein.

\section{DISCUSSION}

On day 24 after fertilization, endoderm tissue of the embryos around the primordial pharynx becomes thicker before finally developing into thyroid primodium (Braun et al., 2007; Begum et al., 2009; Moore et al.). This process takes place together with the development of a tongue which slowly descends along the larynx cavity. At its early stage of development, there is a small tube called "thyroglossal duct" that links thyroid gland with the tongue. This tube dissolves at week 7, which is a time when thyroid gland fully develops (Moore \& Persuad; Saddler; Moore et al.). In adults, thyroid gland is located at the front side of the neck at the position of the second to third of tracheal ring which is about the length of the fifth cervical to first thoracic vertebrae (Hollinshead; Marshall; Kaplan; Skandalakis). Thyroid gland consists of left and right lobes, which are attached by isthmus (Ranade et al.; Standring; Phukon et $a l$.). Thyroid gland abnormality was found in this research as a result of the emergence of pyramidal lobe $(8.8 \%)$. In the previous research conducted with different sample groups, with the diversities of the cadavers' nationalities and the places and the times of study, showed that the percentages of thyroid gland abnormality (18-66 \%) were higher than the one found in this research (Braun et al.; Ranade et al.; 
Table III. Abnormality of thyroid gland compared with other previous studies.

\begin{tabular}{|c|c|c|c|c|c|}
\hline Authors & Country & Sample size & $\begin{array}{l}\text { Pyramidal } \\
\text { lobe (\%) }\end{array}$ & $\begin{array}{l}\text { Levator glandulae } \\
\text { thyroideae }(\%)\end{array}$ & $\begin{array}{c}\text { Pyramidal lobe combined } \\
\text { Levator glandulae } \\
\text { thyroideae }(\%)\end{array}$ \\
\hline Braun, et al. (2007) & Austria & 58 & 55 & - & - \\
\hline Ranade et al. (2008) & Southern India & 105 & 58 & 49.5 & 21.6 \\
\hline Begum et al. (2009) & Bangladesh & 60 & 26.7 & 15 & - \\
\hline Joshi et al. (2010) & Maharashtra India & 90 & 37.8 & 30 & - \\
\hline Ozgur et al. (2011) & Turkey & 40 & 60 & 17.5 & - \\
\hline Zivic et al. (2011) & Serbia & 100 & 61 & - & - \\
\hline Prakash et al. (2012) & Karnataka India & 70 & 66 & 62.4 & - \\
\hline Park, et al. (2012) & South Korea & 327 & 41.3 & - & - \\
\hline Cengiz, et al. (2013) & Turkey & 866 & 18 & - & - \\
\hline Mortensen et al. (2014) & United kingdom & 416 & 21.6 & - & - \\
\hline Veerahanumaiah et al. (2015) & Mysore India & 89 & 46 & 41 & - \\
\hline Gurleyik et al. (2015) & Turkey & 166 & 65.7 & - & - \\
\hline Rajkonwar \& Kusre (2016) & Northeast India & 80 & 38.7 & 8.7 & - \\
\hline Kaklamanos et al, (2017) & Greece & 1 & 100 & - & - \\
\hline Present study & Northeastern Thais & 45 & 8.0 & 2.2 & 8.8 \\
\hline
\end{tabular}

Begum et al.; Joshi et al.; Ozgur et al., 2011; Zivic et al., 2011; Park et al., 2012; Cengiz et al., 2013; Mortensen et al., 2014; Veerahanumaiah et al.; Gurleyik et al., 2015; Prakash et al.; Rajkonwar \& Kusre). In 2017, there was a reported case with pyramidal lobe emergence (Gurleyik et al.) (Table III). With regard to the dissecting position of the pyramidal lobe, it was found in this research that the pyramidal lobe was more frequently evolved on the right lobe thyroid gland than on the left lobe counterpart. On the contrary, a 2014 research and other research done previously found that pyramidal lobes separated more frequently on the left lobe of the thyroid gland than on the right lobe (Ozgur et al.; Phukon et al.; Prakash et al.; Cengiz et al.; Gurleyik et al.; Rajkonwar \& Kusre). In this research, the abnormality of thyroid gland was found equally in male and female samples. However, the results obtained from the previous study showed a switching result, because in some research, pyramidal lobe was found more frequent among female samples (Cengiz et al.; Gurleyik et al.) while on other studies males were found with a higher rate of pyramidal lobe females (Prakash et al.; Mortensen et al.). In addition to the finding of pyramidal lobe abnormality, what was highlighted in this research is the alteration of the edge of pyramidal lobe. The mutation of the end of the lobe creates a fibromuscular band that attaches to hyoid cartilage. The fibrous band is known as levator glandulae thyroideae (Moore \& Persuad; Standring; Chaudhary et al.). The occurrence rate of this found in this research $(2.2 \%)$ was relatively small compared to the rate found in other studies (between 15 to $62.4 \%$ ) (Ranade et al.; Begum et al.; Joshi et al.; Ozgur et al.; Prakash et al.; Veerahanumaiah et al.; Rajkonwar \& Kusre). The type III of thyroid gland abnormality found in this research was the combined abnormality of pyramidal lobe and Levator glandulae $(8.8 \%)$. In another study, however, this abnormality was found at $21.6 \%$ (Ranade et $a l$.). These thyroidal gland abnormality are susceptible to the operation of radiology physicians and surgeons in thyroidectomy and tracheostomy performances (Gurleyik et al.; Sinos \& Sakorafas, 2015; Kaklamanos et al., 2017). Being well acknowledge about the thyroidal anatomical change crucial step prior to giving treatment to the patients with thyroid gland abnormality (Rajkonwar \& Kusre). The data yielded from this research is a crucial reference for the frequency of thyroid gland abnormality recurring among people in the northeastern part of Thailand.

MANEENIN, C.; MANEENIN, N. \& IAMSAARD, S. Variaciones anatómicas de las glándulas tiroides en cadáveres embalsamados del noreste de Tailandia. Int. J.Morphol., 37(1):136-140, 2019.

RESUMEN: El objetivo de este estudio fue investigar los patrones de variación de la glándula tiroides en cadáveres embalsamados donados para estudios e investigaciones anatómicas en el noreste de Tailandia. El estudio transversal descriptivo se aplicó para observar sistémicamente la glándula tiroides en caso de anomalía en 45 cadáveres embalsamados. El estudio se realizó en el Laboratorio de Anatomía de la Facultad de Medicina y Salud Pública de la Universidad de Ubon Ratchathani. Las anomalías de la glándula tiroides se registraron mediante fotografías antes de la clasificación de los datos y se utilizaron en un análisis descriptivo con SPSS. Los resultados mostraron que en 8 de los 45 cadáveres $(17,8 \%)$ se observaron anomalías de la glándula tiroides (4 hombres; $8,9 \%$ y 4 mujeres; $8,9 \%$ ). Tales variaciones podrían ser clasificadas en 3 tipos: lóbulo piramidal $(8,8 \%)$, músculo elevador de la glándula tiroides $(2,2 \%)$ y la coexistencia del músculo elevador de la glándula tiroides $(8,8 \%)$, respectivamente. La anoma- 
lía de la glándula tiroides observada en este estudio se relacionó principalmente con informes anteriores. Además, la cantidad de variaciones tiroideas es una indicación crucial de la anomalía de la glándula tiroides que se repite, esta anomalía de la glándula es susceptible a las intervenciones de los médicos radiólogos en la tiroidectomía y la traqueotomía.

PALABRAS CLAVE: Variaciones anatómicas; Glandula tiroides; Lóbulo piramidal; Músculo elevador de la glándula tiroides.

\section{REFERENCES}

Begum, M.; Khatun, M.; Kishwara, S.; Ahmed, R. \& Naushaba, J. A postmortem study of the pyramidal lobe of the thyroid gland in bangladeshi people. J. Dhaka Med. Coll., 18(2):120-3, 2009.

Braun, E. M.; Windisch, G.; Wolf, G.; Hausleitner, L. \& Anderhuber, F. The pyramidal lobe: clinical anatomy and its importance in thyroid surgery. Surg. Radiol. Anat., 29(1):21-7, 2007.

Cengiz, A.; Sakı, H. \& Yürekli, Y. Scintigraphic evaluation of thyroid pyramidal lobe. Mol. Imaging Radionucl. Ther., 22(2):32-5, 2013.

Chaudhary, P.; Singh, Z.; Khullar, M. \& Arora, K. Levator glandulae thyroideae, a fibromusculoglandular band with absence of pyramidal lobe and its innervation: a case report. J. Clin. Diagn. Res., 7(7):14214, 2013.

Gurleyik, E.; Gurleyik, G.; Dogan, S.; Cobek, U.; Cetin, F. \& Onsal, U. Pyramidal lobe of the thyroid gland: surgical anatomy in patients undergoing total thyroidectomy. Anat. Res. Int., 2015:384148, 2015.

Hollinshead, W. H. Anatomy for Surgeons. The Head and Neck. Vol. 2. New York, Hoeber-Harper, 1961.

Joshi, S. D.; Joshi, S. S.; Daimi, S. R. \& Athavale, S. A. The thyroid gland and its variations: a cadaveric study. Folia Morphol. (Warsz), 69(1):4750, 2010.

Kaklamanos, I.; Zarokosta, M.; Flessas, I.; Zoulamoglou, M.; Katsoulas, T.; Birbas, K.; Troupis, T. \& Mariolis-Sapsakos, T. Surgical anatomy of double pyramidal lobe on total thyroidectomy: a rare case report. $J$. Surg. Case Rep., 2017(3):rjx035, 2017.

Kaplan, E. L. Thyroid and Parathyroid. In: Schwartz, S. I. (Ed.). Principles of Surgery. 6th ed. New York, McGraw-Hill, 1994. pp.1612.

Marshall, C. F. Variations in the form of the thyroid gland in man. J. Anat. Physiol., 29(Pt. 2):234-9, 1895.

Moore, K. L. \& Persaud, T. V. N. The Developing Human: Clinically Oriented Embryology. 7th ed. Philadelphia, Saunders, 2003. pp.215-7.

Moore, K. L.; Persaud, T. V. N. \& Torchia, M. G. The Developing Human: Clinically Oriented Embryology. $9^{\text {th }}$ ed. Philadelphia, Elsevier, 2013. pp.173-4.

Mortensen, C.; Lockyer, H. \& Loveday, E. The incidence and morphological features of pyramidal lobe on thyroid ultrasound. Ultrasound, 22(4):192-8, 2014.

Ozgur, Z.; Celik, S.; Govsa, F. \& Ozgur, T. Anatomical and surgical aspects of the lobes of the thyroid glands. Eur. Arch. Otorhinolaryngol., 268(9):1357-63, 2011.

Park, J. Y.; Kim, D. W.; Park, J. S.; Kang, T. \& Kim, Y. W. The prevalence and features of thyroid pyramidal lobes as assessed by computed tomography. Thyroid, 22(2):173-7, 2012.

Phukon, M. J.; Dutta, R.; Reddy, G. N.; Bhargabhi, P. \& Syed, N. A. Right sided pyramidal lobe of thyroid gland - A case report. Int. J. Biol. Med. Res., 3(2):1839-41, 2012.

Prakash; Rajini, T.; Ramachandran, A.; Savalgi, G. B.; Venkata, S. P. \& Mokhasi, V. Variations in the anatomy of the thyroid gland: clinical implications of a cadaver study. Anat. Sci. Int., 87(1):45-9, 2012.
Rajkonwar, A. J. \& Kusre, G. Morphological variations of the thyroid gland among the people of upper assam region of Northeast India: a cadaveric study. J. Clin. Diagn. Res., 10(12):AC01-03, 2016.

Ranade, A. V.; Rai, R.; Pai, M. M.; Nayak, S. R.; Prakash; Krisnamurthy \& Narayana, S. Anatomical variations of the thyroid gland: possible surgical implications. Singapore Med. J., 49(10):831-4, 2008.

Saddler, T.W. Langman's Medical Embryology. Thyroid Gland. $11^{\text {th }}$ ed. Philadelphia, Lippincott Williams and Wilkins, 2010. pp.278.

Sinos, G. \& Sakorafas, G. H. Pyramidal lobe of the thyroid: anatomical considerations of importance in thyroid cancer surgery. Oncol. Res. Treat., 38(6):309-10, 2015.

Skandalakis, J. E. Skandalakis' Surgical Anatomy. The Embryologic and Anatomic Basis of Modern Surgery. Athens, PMP, 2004. pp.47-56.

Standring, S. Gray's Anatomy. The Anatomical Basis of Clinical Practice. $40^{\text {th }}$ ed. Edinburgh, Churchill Livingstone/Elsevier, 2008.

Veerahanumaiah, S.; Dakshayani, K. R. \& Menasinkai, S. B. Morphological variations of the thyroid gland. Int. J. Res. Med. Sci., 3(1):53-7, 2015.

Wayne, W. D. Biostatistics: A Foundations of Analysis in the Health Sciences. $6^{\text {th }}$ ed. New York, John Wiley \& Sons, 1995. pp.180.

Zivic, R.; Radovanovic, D.; Vekic, B.; Markovic, I.; Dzodic, R. \& Zivaljevic, V. Surgical anatomy of the pyramidal lobe and its significance in thyroid surgery. S. Afr. J. Surg., 49(3):110, 2011.

Corresponding author:

Dr. Chanwit Maneenin

Department of Anatomy

College of Medicine and Public Health

Ubon Ratchathani University

Ubon Ratchathani, 34190

THAILAND

E-mail : chanwit.m@ubu.ac.th

Received: 12-07-2018

Accepted: 16-10-2018 